\title{
Spanish Lymphoma Group (GELTAMO) guidelines for the diagnosis, staging, treatment, and follow-up of diffuse large B-cell lymphoma
}

Eva González-Barca1, Mónica Coronado², Alejandro Martín ${ }^{3}$, Carlos Montalbán ${ }^{4}$, Santiago Montes-Moreno5, Carlos Panizo', Guillermo Rodríguez, Juan Manuel Sancho $^{8}$, Andrés López-Hernández ${ }^{9}$ and on behalf of the Spanish Lymphoma Group (GELTAMO)

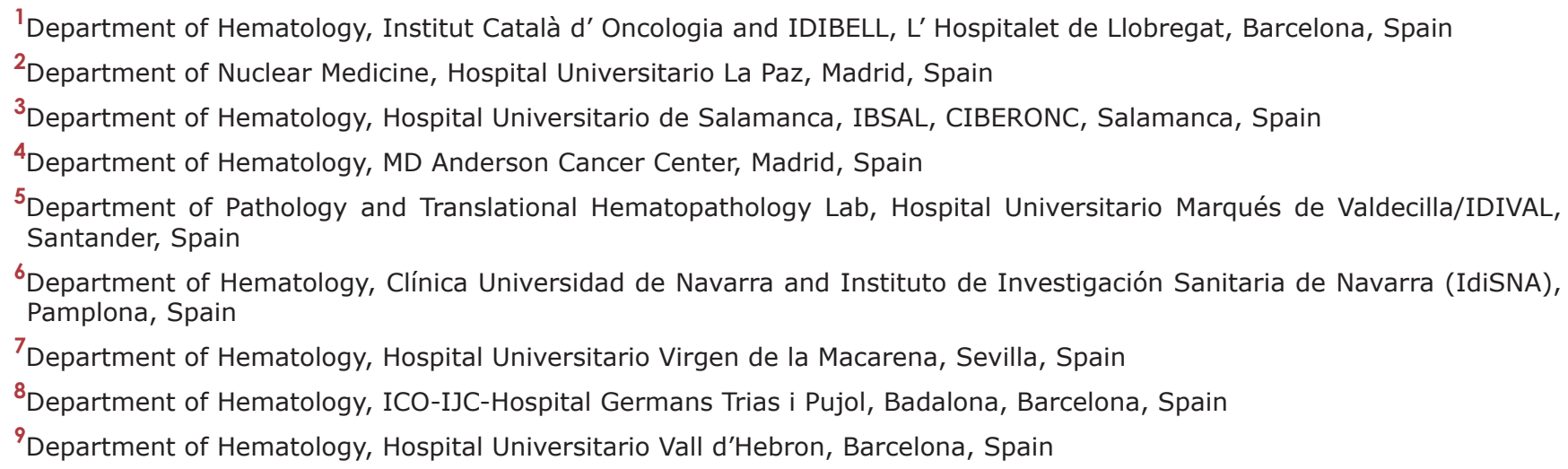
Correspondence to: Eva González-Barca, email: e.gonzalez@iconcologia.net Keywords: guidelines; DLBCL; risk assessment; treatment; DLBCL entities

Received: March 21, $2018 \quad$ Accepted: July 23, $2018 \quad$ Published: August 17, 2018

Copyright: González-Barca et al. This is an open-access article distributed under the terms of the Creative Commons Attribution License 3.0 (CC BY 3.0), which permits unrestricted use, distribution, and reproduction in any medium, provided the original author and source are credited.

\section{ABSTRACT}

Diffuse large B-cell lymphoma (DLBCL) accounts for approximately $\mathbf{3 0} \%$ of non-Hodgkin lymphoma (NHL) cases in adult series. DLBCL is characterized by marked clinical and biological heterogeneity, encompassing up to 16 distinct clinicopathological entities. While current treatments are effective in $60 \%$ to $70 \%$ of patients, those who are resistant to treatment continue to die from this disease.

An expert panel performed a systematic review of all data on the diagnosis, prognosis, and treatment of DLBCL published in PubMed, EMBASE and MEDLINE up to December 2017. Recommendations were classified in accordance with the Grading of Recommendations Assessment Development and Evaluation (GRADE) framework, and the proposed recommendations incorporated into practical algorithms. Initial discussions between experts began in March 2016, and a final consensus was reached in November 2017. The final document was reviewed by all authors in February 2018 and by the Scientific Committee of the Spanish Lymphoma Group GELTAMO.

\section{DIAGNOSIS}

Surgical excision/incision biopsy of a node or affected extra-nodal tissue is the method of choice for diagnosis. Core needle biopsies may be performed in patients in whom surgical biopsy is excessively risky. Diagnosis is not based exclusively on the analysis of fine-needle aspirate, although this technique, together with adequate phenotyping, can be sufficient to confirm relapse [1]. 
Diagnosis of DLBCL is based on morphological, immunohistochemical, cytogenetic, and molecular analyses. DLBCL is characterized by the expression of pan B markers such as CD20, paired box protein 5 (PAX5), octamer transcription factor 2 (OCT2), and CD79a, which are detectable by immunohistochemistry (IHC) or flow cytometry [1]. Some entities, such as plasmablastic lymphoma, primary effusion lymphoma, anaplastic lymphoma kinase (ALK)-positive large B-cell lymphoma, and human herpes virus-8 (HHV-8)-positive DLBCLnot otherwise specified (NOS) show reduced expression of markers of B-cell differentiation and upregulation of plasma-cell differentiation antigens. In these cases, analyses of CD138, CD38, Ki67, MYC, multiple myeloma-1 (MUM1), ALK, HHV-8, and Epstein-Barr virus (EBV)encoded small RNAs (EBERs) are recommended [1].

At least 2 molecular subtypes of DLBCL-NOS have been identified by gene expression profiling: the germinal center B-cell-like (GCB) and the activated B-cell-like $(\mathrm{ABC})$, which differ in their prognosis [2]. These subtypes can be classified using a variety of immunohistochemical algorithms, which range in accuracy from $85 \%$ to $93 \%$ with respect to the gold standard (gene expression profiling) $[3,4]$. The Hans algorithm demonstrated prognostic value for progression-free survival (PFS), although making therapeutic decisions based on these result is not currently supported by available evidence. Double protein (DP) expression of MYC and BCL2 is found in $20 \%$ to $35 \%$ of cases [5-7]. These cases are associated with worse survival in retrospective series, regardless of subtype (GCB vs. $\mathrm{ABC}$ ). While it is recommended to note double MYC/BCL2 expression, there is insufficient evidence to suggest that an alternative therapeutic approach should be taken based on this parameter. CD30 expression is observed in 14\% to $25 \%$ of cases, and is more common in certain entities, such as primary mediastinal large B cell lymphoma. It is recommended to report its expression at diagnosis $[8,9]$.

Studies have described cases characterized by concurrent rearrangements of $M Y C$ and $B C L 2$ and/or $B C L 6$ (double/triple hit: DH/TH) [5-7, 10]. These cases account for $3 \%$ to $14 \%$ of DLBCL and over $30 \%$ of cases formerly classified as B-cell lymphoma with features intermediate between DLBCL and Burkitt lymphoma. These cases are usually diagnosed in advanced stages with frequent involvement of the bone marrow and central nervous system (CNS), show a GCB phenotype and MYC protein overexpression in most instances, and have an adverse prognosis $[11,12]$. Demonstration of $M Y C, B C L 2$ and $B C L 6$ rearrangements can be done using FISH (fluorescent in situ hybridization) or conventional cytogenetic techniques. Cases with DLBCL morphology and DH/TH are now classified as High Grade B cell Lymphoma DH/TH, based on 2016 World Health Organization (WHO) classification update.

\section{Summary and recommendations for DLBCL diagnosis (Figure 1)}

1. Excisional/incisional biopsy of the adenopathy or affected extranodal tissue is the method of choice for the diagnosis of DLBCL (Grade 1A).

2. Diagnosis of DLBCL is based on the results of histopathological, immunohistochemical, and cytogenetic/ molecular studies. The combination of this information with clinical data allows classification according to the WHO (Grade 1A).

3. In all cases of DLBCL-NOS it is recommended to classify according to $\mathrm{GCB} /$ non-GCB phenotype, using the Hans algorithm (Grade 2B).

4. It is advisable to evaluate expression of MYC and BCL2 in DLBCL samples (Grade 2A).

5. Rearrangements of $M Y C, B C L 2$, and/or BCL6 can be demonstrated using conventional cytogenetic techniques (karyotype) and/or FISH; this is a requirement for the diagnosis of cases of high-grade $\mathrm{B}$ cell lymphoma with $\mathrm{DH} / \mathrm{TH}$ (Grade 2A).

6. It is recommended to establish the presence or absence of CD30 expression by IHC in DLBCL samples at diagnosis (Grade 2B).

\section{STAGING AND RISK ASSESSMENT}

A complete clinical history, including Eastern Cooperative Oncology Group (ECOG) functional status and the presence of B symptoms, and a complete physical examination, with particular emphasis on identifying lymphadenopathy and visceromegaly, are required, in addition to the following analyses: blood count; biochemical analysis including lactate dehydrogenase (LDH), beta2 microglobulin, urate, liver and renal function; proteinogram; and serology for hepatitis $\mathrm{B}$ (HBs antigen, anti-HBc), hepatitis $\mathrm{C}$, and human immunodeficiency virus (HIV).

Fluorodeoxyglucose (FDG)-positron emission tomography (PET)/computed tomography (CT) is the test of choice for diagnosis of DLBCL extension, as it offers greater diagnostic accuracy than $\mathrm{CT}$ with contrast owing to its greater sensitivity for the detection of disease [13]. At present there is insufficient evidence to recommend the routine use of PET/CT with high-dose CT with intravenous contrast; the use of this procedure rarely results in changes to patient management and entails an increase in the radiation to which the patient is exposed. PET/CT is of limited value for the detection of CNS disease, and therefore magnetic resonance imaging (MRI) or cerebrospinal fluid (CSF) analysis is recommended in cases of suspected infiltration [13]. Staging by bonemarrow biopsy can be avoided in cases in which PET/CT reveals focal infiltration [13]. 
Measurement of ventricular ejection fraction is recommended in patients over 60 years of age and those with a history of cardiac disease.

The International Prognostic Index (IPI) is used in clinical practice to assess patient prognosis [14], with the limitation that it does not allow identification of very highrisk patients who have undergone immunochemotherapy [15]. Further independent studies are required to validate the proposed greater effectiveness of newer indices, including the National Comprehensive Cancer Network (NCCN)-IPI and GELTAMO-IPI [16, 17]. The inclusion of biomarkers and genes implicated in the biology of DLBCL has not significantly improved the prognostic accuracy of the IPI $[18,19]$. The presence of concurrent $M Y C$ plus $B C L 2$ and/or BCL6 rearrangements $(\mathrm{DH} / \mathrm{TH})$ confers an adverse prognosis, and is associated with an estimated 9 -fold increase in the risk of mortality $[11,12,20]$.

\section{Summary and recommendations for DLBCL staging and risk assessments}

1. PET/CT is the standard method for the staging of patients with DLBCL, both in clinical practice and in clinical trials (Grade 1B).

2. Bone marrow biopsy can be avoided in cases in which PET/CT reveals bone infiltration (Grade 2C).

3. The IPI is the standard prognostic index used in clinical practice. It is useful as a prognostic tool to stratify patients in clinical trials (Grade 1A).

4. High grade B cell lymphoma with $\mathrm{DH} / \mathrm{TH}$ (i.e. concurrent translocations of $M Y C$ and $B C L 2$, and/or $B C L O$ ) has an adverse prognosis (Grade 2B).

\section{TREATMENT}

\section{First-line therapy}

First-line treatment can be stratified based on the extent of disease (limited stage or disseminated), the age of the patient, and their IPI score.

\section{Limited stage disease (Ann Arbor I-II)}

In the pre-rituximab era, treatment with 3 cycles of CHOP (cyclophosphamide, doxorubicin, vincristine, and prednisone) followed by radiotherapy of the affected area was established as the standard treatment; this approach resulted in better PFS than 6 cycles of CHOP alone, although with longer follow-up no differences in OS were observed between patients who received radiotherapy and those who did not $[21,22]$. In the rituximab era, 2 randomized trials have been performed. The Lymphoma Study Association (LYSA) group conducted a trial in which patients with non-bulky $(<7 \mathrm{~cm})$ limited-stage DLBCL were treated with 4 cycles of rituximab-CHOP (R-CHOP) and patients with high risk factors were treated with 2 additional cycles of R-CHOP. Those in complete metabolic remission (CMR) after 4 cycles of R-CHOP were randomized to 2 groups: involved-field radiation therapy (IFRT) or observation. No differences in eventfree survival (EFS) (89\% vs. 92\%) or overall survival (OS) (92\% vs. 96\%) were observed [23]. Those who did not achieve CMR after 4 cycles of R-CHOP underwent 2 additional cycles of R-CHOP and IFRT. In the German UNFOLDER study, young patients with bulky limited-stage

\section{MORPHOLOGY}

\section{DIAGNOSIS}

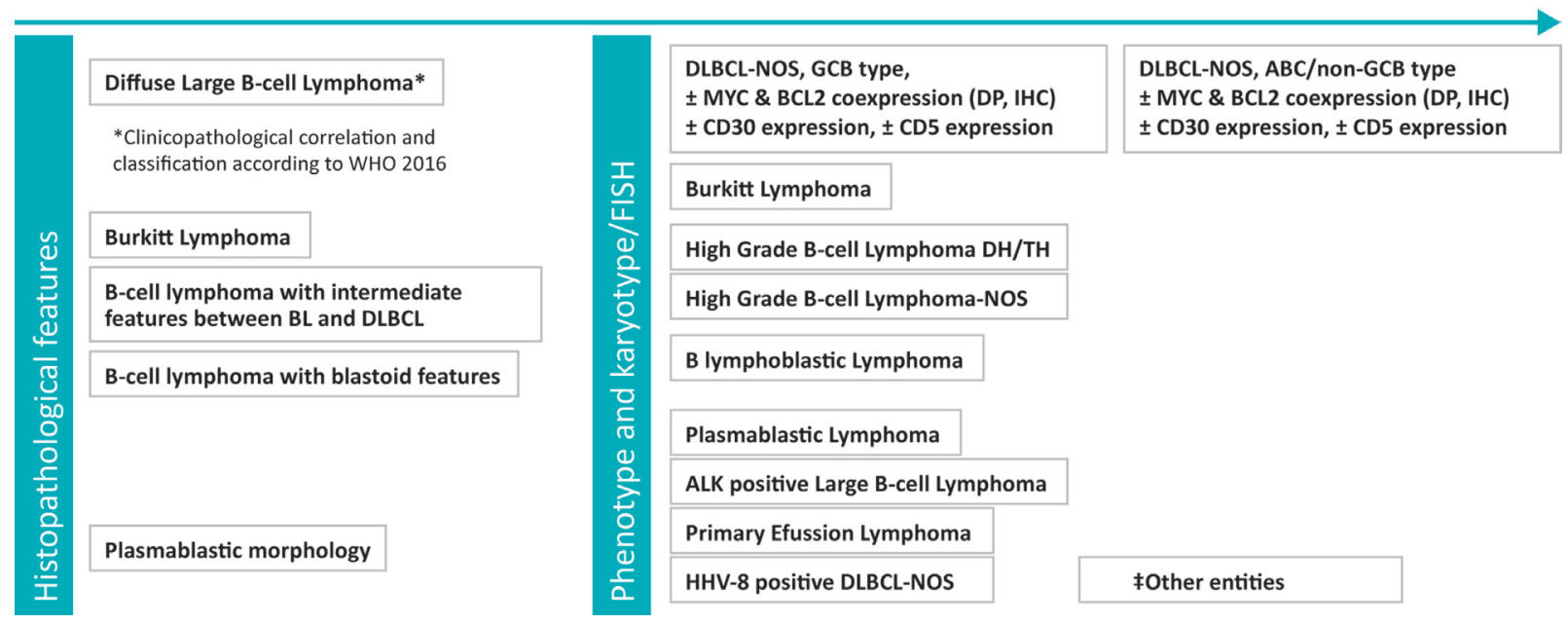

Figure 1: Histopathological diagnosis of DLBCL. Tissue biopsy. ( $\$$ ) Other entities: [T cell/histiocyte-rich large B-cell lymphoma, primary CNS large B-cell lymphoma, primary "leg type" large B-cell lymphoma, EBV-positive large B-cell lymphoma-NOS, DLBCL associated with chronic inflammation, lymphomatoid granulomatosis, primary mediastinal large B-cell lymphoma (thymic), Intravascular large B-cell lymphoma, Burkitt-like lymphoma with 11q aberration, B-cell lymphoma, Unclassifiable, with features intermediate between Hodgkin's lymphoma and DLBCL (grey zone B-cell lymphoma), large B-cell lymphoma with IRF4 rearrangement]. DLBCL: large B-cell lymphoma; NOS: Not otherwise specified. 
DLBCL were randomized to receive 6 cycles of R-CHOP followed by radiotherapy or not. The R-CHOP without radiotherapy arm was prematurely closed due to a high rate of relapse [24], and R-CHOP $\times 6+$ IFRT is therefore recommended for this group of patients.

\section{Disseminated disease (Ann Arbor III-IV)}

\section{Patients aged 60-80 years}

The standard treatment in these patients is 6 to 8 cycles of R-CHOP every 21 days, based on the results of the French group trial that compared this treatment with CHOP without $\mathrm{R}$ and observed a significant increase in survival in the former group [25, 26]. Increasing dose density, which appeared to be beneficial in the RICOVER trial [14, 27], produced no benefits in 2 large randomized trials $[28,29]$. Neither the addition of bortezomib to the R-CHOP-like regimen nor the substitution of rituximab with obinutuzumab (a type II anti-CD20 antibody) improved patient survival $[30,31]$. Use of radiotherapy to treat extranodal lesions or bulky disease is controversial. However, its use is considered based on the findings of a cohort study in which patients that received radiotherapy had better progression-free survival (PFS) [32].

\section{Low or low-intermediate risk patients (IPI score, $0-2)$ aged $<60$ years}

The standard treatment in these patients is 6 to 8 cycles of R-CHOP every 21 days, based on the results of the MiNT trial, which compared R-CHOP-like with CHOP-like regimens and found clear improvements in PFS and OS in patients in whom $\mathrm{R}$ was added $[33,34]$. Patients in this trial with bulky disease received radiotherapy. A French trial of young patients with DLBCL and an age-adjusted (aa)-IPI = 1 compared the most intensive R-ACVBP (rituximabdoxorubicin, cyclophosphamide, vindesine, bleomycin and prednisone)/methotrexate (MTX)/R-ICE (rituximabifosfamide, carboplatin, and etoposide) followed by autologous-hematopoietic stem cell transplantation (autoHSCT) regimen with $\mathrm{R}-\mathrm{CHOP}$, without using radiotherapy in any arm, and observed an increase in survival in patients treated with the intensive regimen, which was also associated with greater toxicity $[35,36]$.

\section{High-risk patients (IPI score, $3-5$ ) aged $<60$ years}

While there is no standard treatment for this group of patients, they are usually treated with 6 to 8 cycles of R-CHOP every 21 days. Dense-dose R-CHOP has shown no benefits [28]. In a phase II study, highrisk patients (IPI: 3-5; aaIPI: 2-3) were treated with DA-EPOCH-R [dose-adjusted-(etoposide, prednisone, vincristine, cyclophosphamide, doxorubicin-rituximab)] [37], and a randomized study (NCT00118209) comparing
DA-EPOCH-R with R-CHOP is currently underway [38]. Some studies have investigated the use of high-dose chemotherapy followed by transplantation of autologous hematopoietic stem cells [39], but have reported contradictory results, and therefore this treatment cannot be recommended for all patients.

\section{Patients with comorbidities or aged $>80$ years}

There is no standard treatment for patients of over 80 years of age. A geriatric assessment is recommended to identify "fit" patients. The combination of rituximab and polychemotherapy with doxorubicin induces complete remission and prolongs survival. Therefore, it is recommended to use conventional treatments such as R-CHOP, or an attenuated immunochemotherapy regimen (R-miniCHOP) [40]. In patients with cardiac pathologies adriamycin can be omitted (R-COP) or substituted with liposomal doxorubicin or other agents such as mitoxantrone, etoposide, or gemcitabine [41-43].

\section{Summary and recommendations for DLBCL first-line therapy (Figure 2)}

1. R-CHOP $\times 4$ cycles is recommended for patients with localized DLBCL without adverse prognostic factors (Grade 1A). For patients with high risk factors in $\mathrm{CR}$ by PET/CT, 2 additional courses of R-CHOP are recommended (Grade 1A). If PET/CT CR is not achieved, the recommendation is to give 2 additional cycles of R-CHOP and IFRT (Grade 1A).

2. R-CHOP $\times 6$ cycles plus radiotherapy of the bulky area is recommended for patients with localized bulky DLBCL ( $>7 \mathrm{~cm}$ ) (Grade 2B).

3. The standard treatment for patients with disseminated DLBCL aged 60 to 80 years is $6-8$ cycles of R-CHOP administered every 21 days (Grade 1A). Radiotherapy for bulky disease or extranodal lesions may be of benefit in some patients (Grade 1B).

4. The standard treatment for patients with disseminated DLBCL aged less than 60 years with an IPI of $0-2$ is 6 cycles of R-CHOP administered every 21 days (Grade 1A). Radiotherapy for bulky disease or extranodal lesions may be of benefit in some patients (Grade 1B).

5. There is no standard treatment for patients with disseminated DLBCL aged less than 60 years with a high IPI (IPI:3-5); these patients should be included in clinical trials. They are generally treated with 6 or 8 cycles of R-CHOP administered every 21 days (Grade 1B).

6. There is no standard treatment for patients with disseminated DLBCL aged over 80 years. It is recommended to use conventional treatments such as R-CHOP whenever possible, or to use attenuated doses of the same drugs (R-miniCHOP) (Grade 1C). Doxorubicin can be replaced with liposomal doxorubicin or other agents such as etoposide, mitoxantrone, or gemcitabine (Grade 1C). 


\section{Salvage therapy}

About $30-40 \%$ of patients have refractory disease or relapses after receiving first-line treatment. It is recommended whenever possible to repeat the biopsy of the tumor tissue to identify false-positive PET/CT or exclude other pathologies [13].

\section{High-dose chemotherapy}

Salvage immunochemotherapy is the treatment of choice in young patients $(<60-70$ years $)$ without comorbidities. In chemosensitive patients, the response should be consolidated with high-dose chemotherapy and auto-HSCT. The superiority of auto-HSCT over consolidation chemotherapy was established in the international randomized PARMA study in the 1990s [44]. No such studies have been performed in the rituximab era. No specific salvage regimen has demonstrated superiority over others. In the international CORAL study, R-DHAP (rituximab-dexamethasone, cytosine arabinoside, and cisplatin) and R-ICE (rituximab-ifosfamide, carboplatin, etoposide) showed similar efficacy, but the former was associated with greater renal toxicity and thrombopenia [45]. In the randomized NCIC-CTG LY.12 international trial, in which patients received R-GDP (rituximab- gemcitabine, cisplatin, and dexamethasone) or R-DHAP, both regimens showed similar efficacy, but R-DHAP resulted in greater toxicity (febrile neutropenia and thrombopenia) [46]. However results are very poor with any of the aforementioned regimens, with PFS around $20 \%$ [47]. Therefore, the best option for these patients is to enroll them in clinical trials of regimens that include new drugs. In this context, the substitution of rituximab with ofatumumab showed no benefit in a randomized study [48].

The main prognostic factor at the time of transplantation is lymphoma status, as determined by PET/CT, since patients with CMR have significantly better survival than patients in partial remission (PR) (PFS: $72 \%-87 \%$ vs. $18 \%-49 \%$ ) $[49,50]$. There are no randomized studies demonstrating the superiority of any conditioning regimen. The BEAM (BCNU, etoposide, cytarabine and melphalan) regimen is the most widely used in Europe. The incorporation of radioimmunotherapy into the conditioning regimen showed no superiority in the only phase III clinical trial published to date [51]. Maintenance rituximab after auto-HSCT also showed no benefits in the CORAL study [52]. Several retrospective studies have reported that allogeneic hematopoietic stem cell transplantation (allo-HSCT) may be effective in patients with relapse or progression after multiple lines

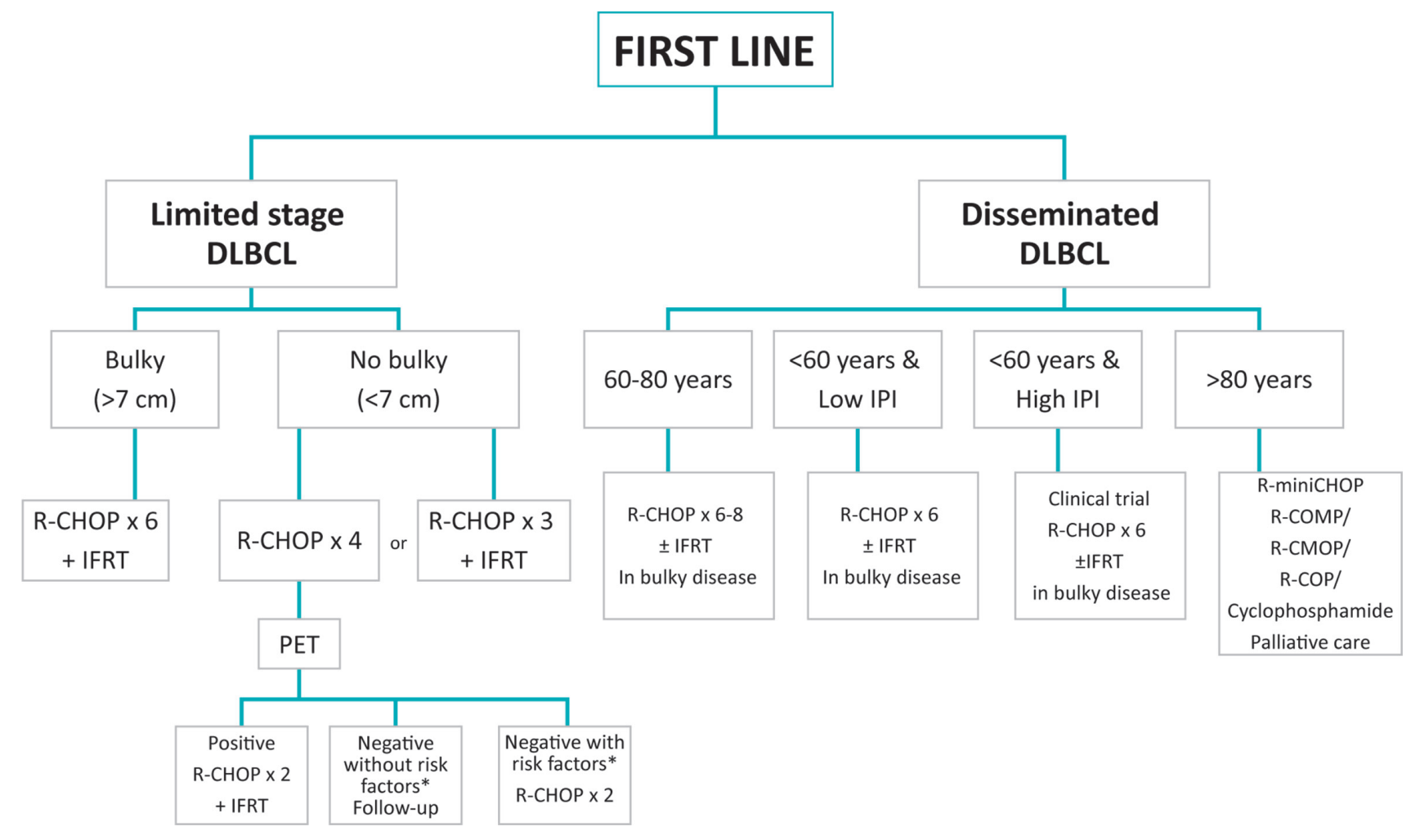

Figure 2: First line therapy. "Risk factors: High LDH level, Ann Arbor stage II, ECOG PS > 0, Age > 60 years. DLBCL: large B cell lymphoma; IFRT: involved-field radiation therapy; IPI: international prognostic index; R-CHOP: rituximab, cyclophosphamide, daunorubicin (doxorubicin), vincristine, prednisone; R-COMP: rituximab, cyclophosphamide, doxorubicin, vincristine and prednisone; RCOP: rituximab, cyclophosphamide, vincristine, prednisone. 
of treatment, including auto-HSCT [53-55]. Given that myeloablative regimens are associated with a very high non-relapse-related mortality rate $(40 \%-50 \%)$, it seems advisable to use non-myeloablative regimens (mortality: 20\%-30\% ; PFS: $20 \%-40 \%$ ). The status of the lymphoma is the most important prognostic factor, with very poor results in patients with chemorefractory disease [53-55]. In high-risk patients in PR after salvage therapy, alloHSCT may be an alternative to auto-HSCT [56]. In controlled studies, allo-HSCT could be also an alternative to auto-HSCT [57, 58], for patients with very high-risk features, such as primary refractory disease.

\section{Non-auto-HSCT candidates}

Evidence supporting the efficacy of salvage regimens in these patients is based on phase II studies. There is no standard regimen established and durable remissions are uncommon.

R-GemOx (rituximab-gemcitabine, oxaliplatin) results in overall response rates (ORR) of about $60 \%$ with a 1-year OS rate of $45 \%$ and a PFS of around $25 \%$ at 12 months $[59,60]$. While results obtained with R-bendamustine (rituximab-bendamustine) in phase II trials vary significantly, this regimen has an acceptable toxicity profile and is relatively efficacious (ORR > 30\%) in frail patients [61]. However, whenever possible these patients should be enrolled in clinical trials.

\section{Third-line and later lines of therapy}

Third-line therapy is an option in patients who do not respond to salvage treatment. The scientific evidence supporting the efficacy of third-line therapy is lower than that published for previous lines of therapy. In some cases patients may be treated with second-line polychemotherapy regimens not used previously. A study comparing pixantrone monotherapy with other chemotherapeutic agents in monotherapy in relapsed patients that previously received a median of 3 lines of therapy reported overall response rates of $40 \%$ for pixantrone versus $14.3 \%$ for the comparator arm [62]. Lenalidomide in monotherapy or combined with rituximab shows efficacy in this situation, producing an overall response rate of around $30 \%$, with a relatively short-duration response $[63,64]$. Despite the higher ORR observed for the non-GCB subtype, no differences in PFS or OS were detected between the GCB and nonGCB subtypes [65]. There are no clinical trial data to indicate which other drugs in monotherapy (gemcitabine, oxaliplatin, etoposide, mitoxantrone, vinorelbine) are most appropriate in each case. These treatments have been used in comparator arms in several phase II clinical trials, and have shown poor efficacy in terms of ORR (usually $<20 \%$ ), but some clinical benefits [62]. Efficacy data are available for 2 treatment regimens at metronomic doses: celecoxib, methotrexate, and cyclophosphamide, which produced an ORR of 30\% [66], and the PEP-C (prednisone, etoposide, procarbazine- cyclophosphamide) regimen, which produced a response in 3 out of 9 patients with DLBCL, with high toxicity [67]. Inclusion of these patients in clinical trials is recommended wherever possible.

\section{Summary and recommendations for DLBCL salvage therapy (Figure 3)}

1. In refractory disease or relapse, it is advisable to repeat the tumor biopsy before proceeding to second-line treatment (Grade 1B).

2. The salvage regimen with the most favorable toxicity profile is R-GDP, although other regimens such as R-ESHAP, R-DHAP, and RICE have shown similar efficacy (Grade 1B). Patients who achieve at least PR following salvage therapy should undergo auto-HSCT with BEAM or similar conditioning regimen (Grade 1B).

3. Allogeneic transplantation is an option in patients that relapse after auto-HSCT (Grade 1C).

4. In patients with refractory or relapsing DLBCL who are not candidates for auto-HSCT, moderate-to-low intensity regimens using $\mathrm{R}-\mathrm{GemOx}$ or $\mathrm{R}$-bendamustine are recommended (Grade 1B).

5. There are no specific recommendations for third or later lines of therapy. Pixantrone has demonstrated superiority over other drugs in monotherapy in relapsed patients (Grade 1B).

\section{RESPONSE EVALUATION AND FOLLOW-UP}

$\mathrm{PET} / \mathrm{CT}$ at the end of treatment is the best instrument for assessing the patient's response. It is recommended to apply the criteria of the Lugano classification system, using the Deauville 5-point scale. The presence of a residual mass in the context of CMR is not a criterion for active disease. In cases of metabolically active residual disease, it is advisable to perform a biopsy if salvage therapy is considered $[13,68]$.

Interim PET (iPET)/CT is used to assess the early response, but there are some problems due to standardization regarding the technique itself and its interpretation [13]. CMR on iPET carries an excellent prognosis. Studies evaluating intensification treatment based on iPET have shown no benefit over R-CHOP $[69,70]$. Therefore, iPET is not recommended as a basis for altering treatment outside of clinical trials.

After achieving CMR, clinical follow-up, with clinical history, physical examination, and laboratory work-up, should be performed every 3 to 4 months for the first 2 years and every 6 months for the following 3 years [13]. This should be followed by annual clinical 
follow-up to assess potential late toxicity and the possible development of second neoplasms. There is no evidence to suggest that routine $\mathrm{CT}$ or $\mathrm{PET} / \mathrm{CT}$ provides any advantage over clinical follow-up assessment [13]. Most relapses occur outside of planned follow-up visits and only $1 \%-2 \%$ are detected in imaging tests [71], which provide no advantages for early detection of relapse and have no impact on survival.

\section{Summary and recommendations for DLBCL response evaluation and follow-up}

1. PET/CT is the standard imaging modality used to assess the response at the end of treatment (Grade 1A).

2. Evaluation of the response should be carried out visually using the Deauville scale (Grade 2B).

3 . In cases of metabolically active residual disease, it is advisable to perform a biopsy if salvage therapy is considered (Grade 2C).

4. In clinical practice, iPET is not recommended as a basis for changing treatment, unless there is clear evidence of progression, and should be reserved for clinical trials (Grade 2C).
5. The routine use of imaging tests in the followup of patients with DLBCL in complete remission is discouraged (Grade 1A).

\section{SPECIAL SITUATIONS}

\section{CNS prophylaxis}

This topic has been extensively discussed in recent specific guidelines published by the GELTAMO group [72].

\section{Tumor lysis syndrome prophylaxis}

Risk factors for tumor lysis syndrome (TLS) include bulky tumor burden, a high proliferative index, preexisting renal failure, advanced age, and treatment with highly active cell-cycle-specific agents. Prophylaxis with allopurinol is recommended in patients at intermediate risk of TLS. Treatment should be maintained for up to 7 days [73]. In high-risk patients (bulky disease [ $\geq 10 \mathrm{~cm}], \mathrm{LDH}$ over twice the upper limit of normal, patients in the "MYCdriven" subgroup, and patients with renal impairment)

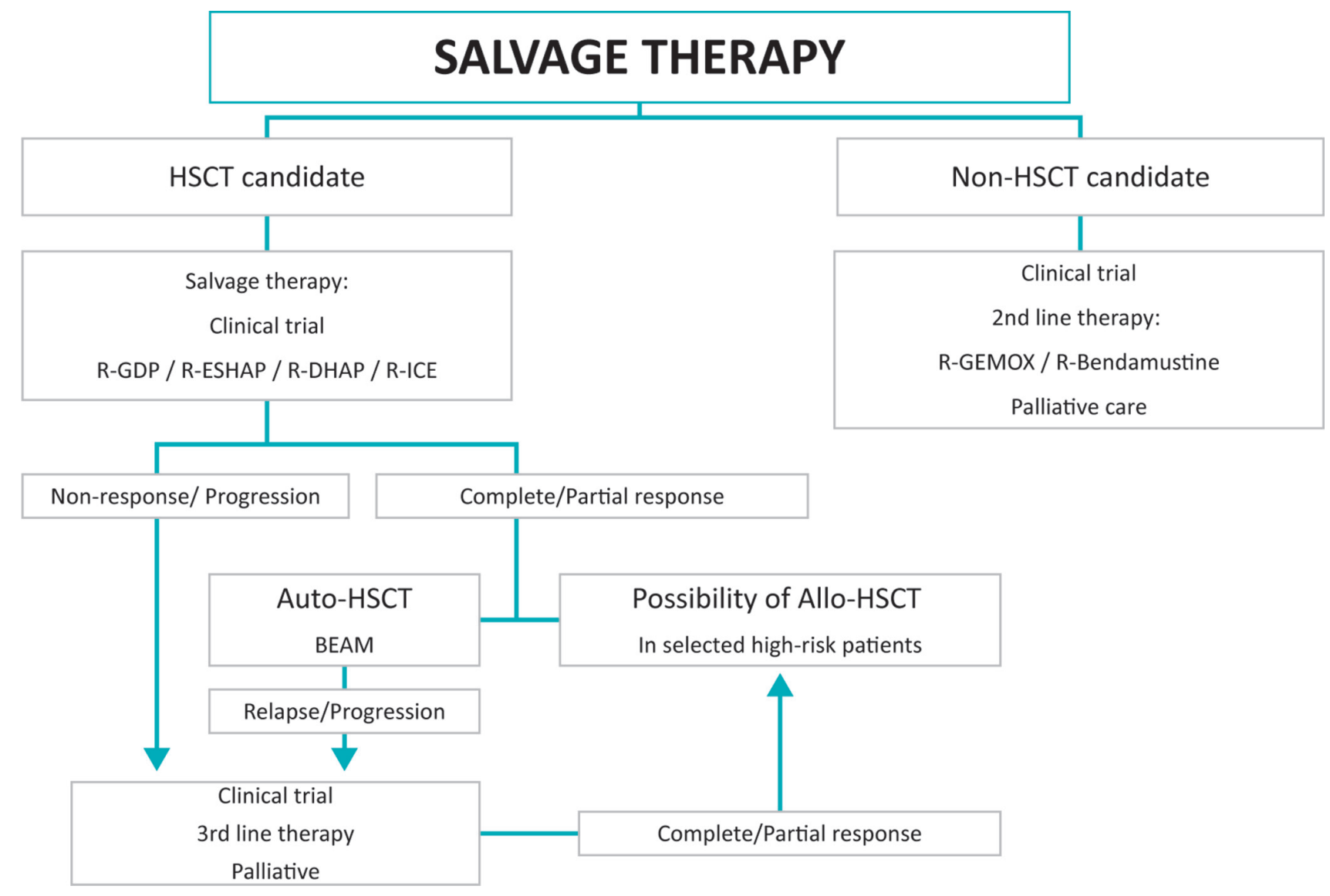

Figure 3: Salvage therapy. BEAM: carmustine, etoposide, cytarabine, melphalan; HSCT: hematopoietic stem cell transplantation; R-DHAP: rituximab, dexamethasone, cytarabine, cisplatin; R-ESHAP: rituximab, etoposide, methylprednisolone; cytarabine; cisplatin; R-GDP: rituximab, gemcitabine, cisplatin, dexamethasone; R-ICE: rituximab, ifosfamide, carboplatin, etoposide. 
$[73,74]$, TLS prophylaxis with hydration and rasburicase is recommended [75]. The volume infused is not specified, but $3 \mathrm{~L} / 24$ hours in adults seems a reasonable estimate. The standard dose of rasburicase is $0.2 \mathrm{mg} / \mathrm{kg}$, for 5-7 days. However, studies have reported the use of lower doses, such as $0.1 \mathrm{mg} / \mathrm{kg} / \mathrm{day}$ or $0.15 \mathrm{mg} / \mathrm{kg} /$ day, with a treatment duration adjusted to the patient's evolution, and the majority of patients only required a single dose $[74,76]$. Concomitant use of rasburicase and allopurinol is not recommended, since the latter can reduce the efficacy of rasburicase.

\section{Summary and recommendations for DLBCL TLS prophylaxis}

1. Patients with low risk TLS should be managed by monitoring water balance and laboratory parameters, and only the administration of allopurinol should be considered (Grade 2C). Intermediate-risk patients should be treated with allopurinol (7 days) and hydration (Grade 2C). High-risk patients should be treated with rasburicase and hyperhydration (Grade 1B).

\section{SPECIAL SUBTYPES}

\section{Plasmablastic lymphoma}

Plasmablastic lymphoma is mainly associated with human immunodeficiency virus (HIV) infection, but it has also been described in patients with other types of immune compromise and in immunocompetent patients $[77,78]$. It usually presents with extranodal involvement, affecting the oral cavity in almost half of all cases. The prognosis is poor, with median survival ranging from $8-15$ months [78]. There is no standard treatment. Some reviews recommend more intensive chemotherapy regimens such as EPOCH (etoposide, doxorubicin, and cyclophosphamide with vincristine and prednisone) or hyper CVAD/MA (hyperfractionated cyclophosphamide, vincristine, doxorubicin, and dexamethasone alternating with methotrexate and cytarabine), especially given the role of $M Y C$ alterations in the pathogenesis of this lymphoma [77]. However, 2 retrospective studies found no survival benefit of intensive regimens over CHOP in HIV patients [79, 80]. The use of CNS prophylaxis has not been systematically evaluated, but seems advisable given the frequent extranodal involvement, the high proliferative index, and the presence of MYC rearrangements in many cases [77]. Loco-regional radiotherapy has been used in some cases, although its role has not been fully established [77]. The use of auto-HSCT remains controversial: while some authors have proposed it as first-line consolidation therapy [81], others propose that it should only be used in cases that fulfill risk criteria $[82,83]$. The incorporation of new drugs has produced promising results in recent studies. These include thalidomide, lenalidomide, and in particular the proteasome inhibitor bortezomib, which when combined with DA-EPOCH [84] or with CHOP [85] followed by auto-HSCT produced long-term remission.

\section{Primary mediastinal B-cell lymphoma (PMBCL)}

This predominantly affects young adults (mainly women aged $30-40$ years) and usually manifests as a bulky mediastinal mass, often with pleural or pericardial effusion and superior vena cava syndrome $[86,87]$. Although there are few prospective studies, some sub-analyses such as the MinT trial [88] (with 11\% of patients with PMBCL) concluded that the addition of rituximab to CHOP-like (CHOP or CHOEP) regimens significantly increased the CR rate and increased 3-year PFS (78\% vs. 52\%, $p=0.01)$ but not OS $(88.5 \%$ vs. $78.2 \%, p=0.15)$, possibly due to the small number of patients in this subgroup. Other retrospective studies have compared R-CHOP with $\mathrm{CHOP}$ regimens, and found that the former provides better outcomes [89]. A prospective phase II NCI study in which patients received infusional DA-EPOCH-R reported a CR rate of $94 \%$, a 5 -year EFS of $93 \%$, and an OS of $97 \%$. Only 2 patients required radiotherapy [86]. However, to date, no prospective study has directly compared DAEPOCH-R with R-CHOP.

The role of radiotherapy is controversial. In a series that included patients treated with R-CHOP, CHOP, and intensive regimens such as MACOP-B (methotrexate, doxorubicin, cyclophosphamide, vincristine, prednisone, and bleomycin) and VACOP-B (etoposide, doxorubicin, cyclophosphamide, vincristine, prednisone, and bleomycin), the addition of radiotherapy had no effect on PFS or OS [90]. The use of DA-EPOCH-R provides good results without the need for radiotherapy [86]. The definitive role of radiotherapy may be clarified upon publication of the results of the International Extranodal Lymphoma Study Group (IELSG-37) study, in which patients who achieve CMR are randomized to radiotherapy or observation arms (https://www.clinicaltrials.gov/; NCT01599559). Frontline consolidation treatment with auto-HSCT does not provide any benefit [91]. Refractoriness and relapse are usually associated with an unfavorable prognosis [92]. Treatment is usually based on salvage immunochemotherapy and consolidation with auto-HSCT, and the results obtained tend to be poorer than those observed for DLBCL-NOS [93].

\section{High-grade lymphoma with $M Y C$ and $B C L 2$ and/ or BCL6 rearrangement (double/triple hit)}

This type of lymphoma usually presents at advanced age, with high LDH and extranodal involvement, especially CNS infiltration [94]. It is important to differentiate DH/ TH lymphomas from those with DP expression of MYC and BCL2. In patients with DH/TH lymphomas, standard 
treatment based on R-CHOP offers poor results with a CR rate of $40 \%$ and $\mathrm{OS}$ at 2 years of $35 \%-40 \%[5,20,95$, 96]. Most intensive chemotherapy regimens, in particular DA-EPOCH-R, appear to achieve better CR and PFS than R-CHOP [5, 20, 97]. However, in a meta-analysis [98] of 11 studies and a total of 394 patients treated with R-CHOP ( $n=180)$, R-EPOCH $(n=91)$, and R-hyper CVAD/R-MA or R-CODOX-M/R-IVAC (rituximab-cyclophosphamide, doxorubicin, vincristine, methotrexate/ifosfamide, etoposide, high-dose cytarabine) $(n=123)$, the risk of progression was significantly lower in R-EPOCH- versus R-CHOP-treated patients, but no significant differences in OS were observed between the 3 regimens, with median OS ranging from 20-30 months. Retrospective studies have corroborated the poor results obtained with autoHSCT in patients with DH lymphoma [99]. Inclusion of these patients in clinical trials is recommended. CNS prophylaxis is highly recommended as it appears to be associated with improved survival [100].

\section{DLBCL in HIV patients}

DLBCL is an AIDS-defining neoplasm. The prognosis of patients with DLBCL before the antiretroviral (ART) era was poor, but since the introduction of highly active ART (HAART), survival is similar to that of non-HIV-infected patients, using the same immunochemotherapy regimens [101, 102]. In these patients adequate antimicrobial prophylaxis and the use of $\mathrm{G}-\mathrm{CSF}$ as primary prophylaxis for febrile neutropenia is recommended. Some studies suggested a higher incidence of CNS infiltration in the pre-ART era [103], but with HAART there has been a decrease in CNS infiltration, and therefore the recommendations for prophylaxis of CNS involvement are the same as for immunocompetent patients.

\section{Post-transplant lymphoproliferative disorder}

Post-transplant lymphoproliferative disorder (PTLD) is one of the most serious complications that can affect patients undergoing solid-organ transplantation or allogeneic stem cell transplantation. Incidence ranges from $1 \%-20 \%$. As a result of the immunodepressive state induced to prevent rejection, $\mathrm{T}$ lymphocytes fail to adequately control the proliferation of EBV-infected B lymphocytes, increasing the likelihood of errors during gene rearrangement, activation of oncogenes, inactivation of suppressor genes, and the development of lymphoma. The WHO classification of PTLD describes 3 types: early lesions which are usually polyclonal; polymorphic PTLD; and monomorphic PTLD, which
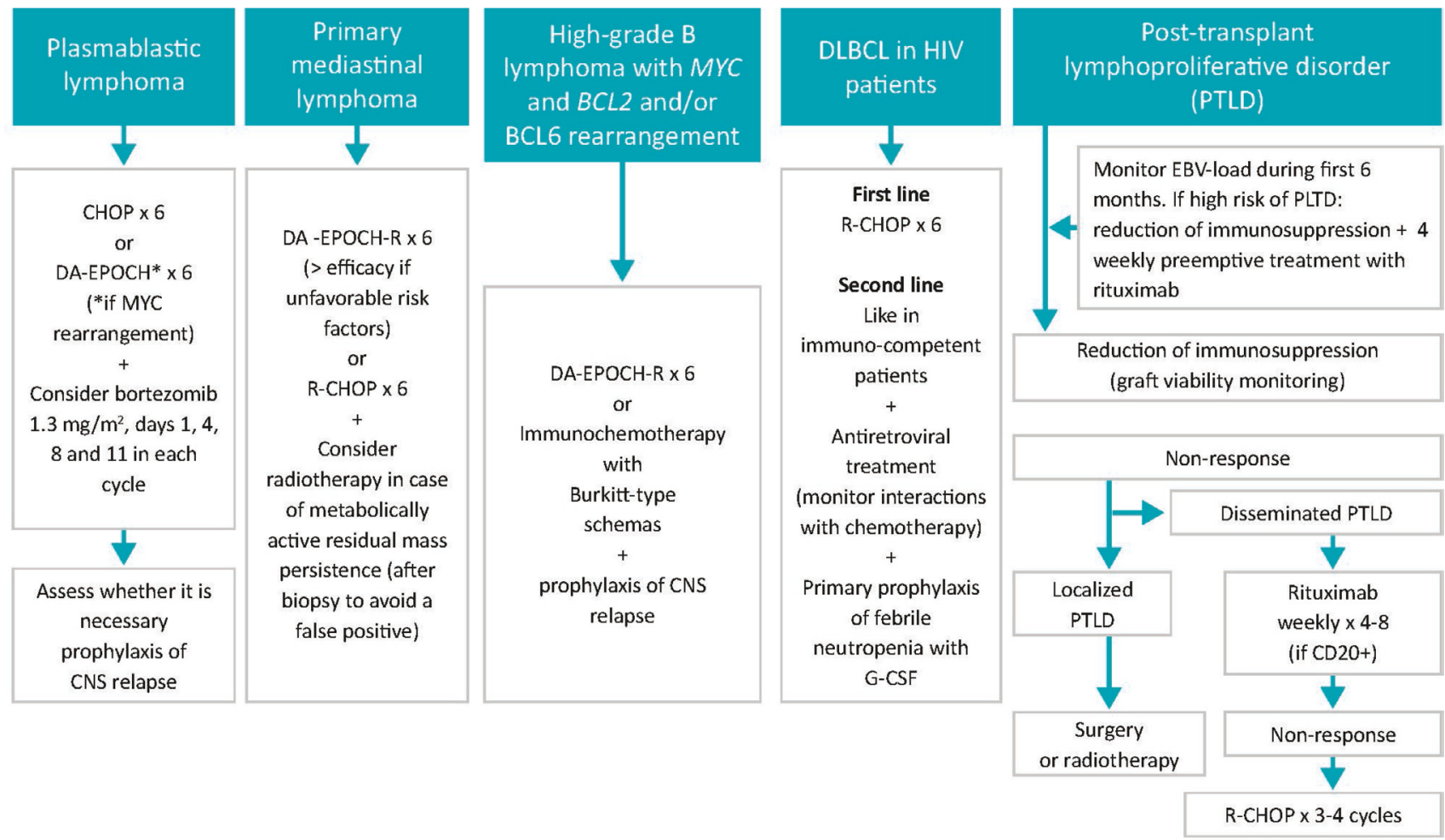

Figure 4: Treatment for special DLBCL subtypes. CNS: central nervous system; DA-EPOCH-R: dose-adjusted, etoposide, prednisone, vincristine, cyclophosphamide, daunorubicin (doxorubicin), rituximab; EBV: Epstein-Barr virus; G-CSF: granulocyte colony stimulating factor; PTLD: post-transplant lymphoproliferative disorder; R-CHOP: rituximab, cyclophosphamide, daunorubicin (doxorubicin), vincristine, prednisone. 
is characterized by conventional-like lymphomas and is usually monoclonal. Most cases of monomorphic PTLD are large B-cell lymphomas. Around a half of all cases appear within 1 year of transplantation. Late-onset cases appear similar to conventional lymphoma, although they are more frequently characterized by extranodal, especially gastrointestinal, involvement. PTLD is staged by PET/CT $[13,68]$. In cases of suspected PTLD, the first step is to reduce immunosuppression without endangering the viability of the graft [104]. This achieves a response rate of $20 \%-50 \%$, particularly in cases of polymorphic PTLD. Localized PTLD can be eradicated by surgical resection or radiotherapy. In cases of disseminated PTLD with CD20 expression, rituximab monotherapy is the treatment of choice, with CR rates of $60 \%-70 \%$ $[105,106]$. If $\mathrm{CR}$ is not achieved, a short course of 3-4 cycles of immunochemotherapy (e.g. R-CHOP) is recommended. Patients who fail to respond to other therapies have been treated with infusions of specific allogeneic cytotoxic $\mathrm{T}$ lymphocytes against EBV, resulting in a CR rate of $45 \%$ [107, 108]. This strategy cannot be applied in all centers due to the high associated costs and the specialized equipment required. In cases of transplant recipients at high risk of PTLD (e.g. recipients of haploidentical hematopoietic stem cell transplants, recipients of multivisceral and heart/lung transplants, and patients who are EBV-negative before transplantation) EBV copy number needs to be monitored frequently during the first 6 months to initiate pre-emptive therapy (1-4 doses of weekly rituximab, depending on the evolution of the viral load) while reducing immunosuppression [109]. There is no standard threshold for treatment initiation. Some authors recommend treatment if copy number exceeds 1000, while others propose thresholds of 10,000 or even 40,000 .

\section{Summary and recommendations for special DLBCL subtypes (Figure 4)}

1. There is no standard treatment for plasmablastic lymphoma. DA-EPOCH is recommended especially in cases with $M Y C$ rearrangement (Grade $2 \mathrm{C}$ ).

2. In patients with primary mediastinal lymphoma, treatment is based on immunochemotherapy with rituximab (Grade 1A). More intensive regimens such as DA-EPOCH-R may be more effective, particularly in cases with unfavorable risk factors (Grade 2B). The effect of complementary radiotherapy in patients who have not achieved CMR is unclear. Whenever possible, it is recommended to repeat the biopsy given the high rate of false positives and the limited value of PET/CT in these cases (Grade 1B).

3. There is no standard therapy for DH/TH lymphomas; these patients should be included in clinical trials. Immunochemotherapy using intensive regimens (e.g. DA-EPOCH-R) or others, such as those used in
Burkitt lymphoma, are recommended (Grade 1B). No data have demonstrated a benefit of auto-HSCT as firstline consolidation therapy in patients with CR (Grade 2C). CNS prophylaxis is recommended (Grade 1C).

4. In HIV patients, the treatment of DLBCL is based on immunochemotherapy, preferably with standard R-CHOP (Grade 2B). Multidisciplinary management is recommended to determine the optimal antiretroviral treatment regimen (Grade 2B). Primary prophylaxis with $\mathrm{G}-\mathrm{CSF}$ is recommended (Grade 2B). In patients with chemosensitive relapse, the same salvage treatments as those used in immunocompetent patients are recommended, followed by consolidation with auto-HSCT (Grade 1B).

5. In PTLD patients, the first recommendation is to reduce immunosuppression (Grade 1B), followed, in CD20-positive cases, by weekly rituximab treatment (4-8 doses). If $\mathrm{CR}$ is not achieved patients may require 3-4 cycles of R-CHOP (Grade 1B). In transplant patients with a high risk of PTLD, monitor EBV copy number during the first 6 months, and institute pre-emptive therapy if copy number increases, reducing immunosuppression and administering 1-4 weekly doses of rituximab, depending on the evolution of the viral load (Grade 1C).

\section{Author contributions}

All authors participated in the conception and design of the work. EGB and AL have coordinated the work and carefully revised the final manuscript. EGB wrote the first draft and all the other authors have reviewed their respective sections. All the authors revised and approved the latest version of the manuscript.

\section{ACKNOWLEDGMENTS}

Our gratefully thank the Scientific Committee of GELTAMO for its unswerving support.

\section{CONFLICTS OF INTEREST}

EGB has received honoraria as speaker from Roche and has served as a consultant to and received compensation from Servier, Sanofi, Gilead, and Janssen. MC declares that she has no relevant or material financial interests that relate to the research described in this paper. AM has received honoraria as a speaker from Celgene, Janssen, Roche, and Servier, honoraria for participating in advisory boards from Gilead, Celgene, Servier, and Roche, and research support from Janssen. CM has received honoraria as a speaker from Takeda. SMM has served as a consultant to and has received compensation from Roche and Takeda. CP has received honoraria as a speaker from Takeda, Janssen, and Roche and has served as a consultant to and received compensation from Servier, Takeda, and Janssen. GR has received honoraria as a speaker from 
Roche, Takeda, Janssen, Celgene, and Servier and has received honoraria for participation in advisory boards from Janssen, Celgene, and BMS. JMS has received honoraria as a speaker from Roche, Gilead, Celgene, Janssen, and Mundipharma, honoraria for participation in advisory boards from Roche, Gilead, Janssen, Sanofi, and Servier, and research support from Teva. AL has received honoraria as a speaker from Servier, Janssen, Gilead, Celgene, and Takeda, honoraria for participation in advisory boards from Gilead, Takeda, and Servier, and research support from Roche. There are no other potential conflicts of interest relevant to this paper to be declared.

\section{REFERENCES}

1. Montes-Moreno S, Mollejo Villanueva M, Fraga M, García JF, Villar JL, Martínez A, Rodríguez Pinilla SM, Battle A, Pulla MP, Rozman M, García Sanz R. Recomendaciones para el estudio histopatológico, inmunohistoquímico, citogenético y molecular e informe diagnóstico de los procesos neoplásicos linfoides. Consenso SEAP-SEHH-GOTEL. En: Libro Blanco de la Anatomía Patológica en España; 2017; 63-174. Available at: https://www.seap.es/libros-blancos.

2. Alizadeh AA, Eisen MB, Davis RE, Ma C, Lossos IS, Rosenwald A, Boldrick JC, Sabet H, Tran T, Yu X, Powell J, Yang L, Marti GE, et al. Distinct types of diffuse large B-cell lymphoma identified by gene expression profiling. Nature. 2000; 403:503-11.

3. Hans CP, Weisenburger DD, Greiner TC, Gascoyne RD, Delabie J, Ott G, Müller-Hermelink HK, Campo E, Braziel RM, Jaffe ES, Pan Z, Farinha P, Smith LM, et al. Confirmation of the molecular classification of diffuse large B-cell lymphoma by immunohistochemistry using a tissue microarray. Blood. 2004; 103:275-82.

4. Choi WW, Weisenburger DD, Greiner TC, Piris MA, Banham AH, Delabie J, Braziel RM, Geng H, Iqbal J, Lenz G, Vose JM, Hans CP, Fu K, et al. A New Immunostain Algorithm Classifies Diffuse Large B-Cell Lymphoma into Molecular Subtypes with High Accuracy. Clin Cancer Res. 2009; 15:5494-502.

5. Johnson NA, Slack GW, Savage KJ, Connors JM, BenNeriah S, Rogic S, Scott DW, Tan KL, Steidl C, Sehn LH, Chan WC, Iqbal J, Meyer PN, et al. Concurrent Expression of MYC and BCL2 in Diffuse Large B-Cell Lymphoma Treated With Rituximab Plus Cyclophosphamide, Doxorubicin, Vincristine, and Prednisone. J Clin Oncol. 2012; 30:3452-9.

6. Green TM, Young KH, Visco C, Xu-Monette ZY, Orazi A, Go RS, Nielsen O, Gadeberg OV, MouritsAndersen T, Frederiksen M, Pedersen LM, Møller MB. Immunohistochemical Double-Hit Score Is a Strong Predictor of Outcome in Patients With Diffuse Large B-Cell Lymphoma Treated With Rituximab Plus Cyclophosphamide, Doxorubicin, Vincristine, and Prednisone. J Clin Oncol. 2012; 30:3460-7.
7. $\mathrm{Hu} \mathrm{S}, \mathrm{Xu}-$ Monette $\mathrm{ZY}$, Tzankov A, Green T, Wu L, Balasubramanyam A, Liu WM, Visco C, Li Y, Miranda RN, Montes-Moreno S, Dybkaer K, Chiu A, et al. MYC/BCL2 protein coexpression contributes to the inferior survival of activated B-cell subtype of diffuse large B-cell lymphoma and demonstrates high-risk gene expression signatures: a report from The International DLBCL Rituximab-CHOP Consortium Program. Blood. 2013; 121:4021-31.

8. Slack GW, Steidl C, Sehn LH, Gascoyne RD. CD30 expression in de novo diffuse large $\mathrm{B}$-cell lymphoma: a population-based study from British Columbia. Br J Haematol. 2014; 167:608-17.

9. $\mathrm{Hu} \mathrm{S}, \mathrm{Xu}-$ Monette ZY, Balasubramanyam A, Manyam GC, Visco C, Tzankov A, Liu WM, Miranda RN, Zhang L, Montes-Moreno S, Dybkaer K, Chiu A, Orazi A, et al. CD30 expression defines a novel subgroup of diffuse large B-cell lymphoma with favorable prognosis and distinct gene expression signature: a report from the International DLBCL Rituximab-CHOP Consortium Program Study. Blood. 2013; 121:2715-24.

10. Scott DW, Mottok A, Ennishi D, Wright GW, Farinha P, Ben-Neriah S, Kridel R, Barry GS, Hother C, Abrisqueta P, Boyle M, Meissner B, Telenius A, et al. Prognostic Significance of Diffuse Large B-Cell Lymphoma Cell of Origin Determined by Digital Gene Expression in FormalinFixed Paraffin-Embedded Tissue Biopsies. J Clin Oncol. 2015; 33:2848-56.

11. Aukema SM, Siebert R, Schuuring E, van Imhoff GW, Kluin-Nelemans HC, Boerma EJ, Kluin PM. Double-hit B-cell lymphomas. Blood. 2011; 117:2319-31.

12. Swerdlow SH. Diagnosis of 'double hit' diffuse large B-cell lymphoma and B-cell lymphoma, unclassifiable, with features intermediate between DLBCL and Burkitt lymphoma: when and how, FISH versus IHC. Hematology Am Soc Hematol Educ Program. 2014; 2014: 90-9. https:// doi.org/10.1182/asheducation-2014.1.90.

13. Cheson BD, Fisher RI, Barrington SF, Cavalli F, Schwartz LH, Zucca E, Lister TA; Alliance, Australasian Leukaemia and Lymphoma Group; Eastern Cooperative Oncology Group; European Mantle Cell Lymphoma Consortium; Italian Lymphoma Foundation; European Organisation for Research; Treatment of Cancer/Dutch Hemato-Oncology Group, et al. Recommendations for initial evaluation, staging, and response assessment of Hodgkin and non-Hodgkin lymphoma: the Lugano classification. J Clin Oncol. 2014; 32:3059-68.

14. International Non-Hodgkin's Lymphoma Prognostic Factors Project. A predictive model for aggressive non-Hodgkin's lymphoma. N Engl J Med. 1993; 329:987-94.

15. Sehn LH, Berry B, Chhanabhai M, Fitzgerald C, Gill K, Hoskins P, Klasa R, Savage KJ, Shenkier T, Sutherland J, Gascoyne RD, Connors JM. The revised International Prognostic Index (R-IPI) is a better predictor of outcome than the standard IPI for patients with diffuse large B-cell lymphoma treated with R-CHOP. Blood. 2007; 109:1857-61. 
16. Zhou Z, Sehn LH, Rademaker AW, Gordon LI, LaCasce AS, Crosby-Thompson A, Vanderplas A, Zelenetz AD, Abel GA, Rodriguez MA, Nademanee A, Kaminski MS, Czuczman MS, et al. An enhanced International Prognostic Index (NCCN-IPI) for patients with diffuse large B-cell lymphoma treated in the rituximab era. Blood. 2014; 123:837-42.

17. Montalbán C, Díaz-López A, Dlouhy I, Rovira J, LopezGuillermo A, Alonso S, Martín A, Sancho JM, García $\mathrm{O}$, Sánchez JM, Rodríguez M, Novelli S, Salar A, et al. Validation of the NCCN-IPI for diffuse large B-cell lymphoma (DLBCL): the addition of $\beta_{2}$-microglobulin yields a more accurate GELTAMO-IPI. Br J Haematol. 2017; 176:918-28.

18. Salles G, de Jong D, Xie W, Rosenwald A, Chhanabhai M, Gaulard P, Klapper W, Calaminici M, Sander B, Thorns C, Campo E, Molina T, Lee A, et al. Prognostic significance of immunohistochemical biomarkers in diffuse large B-cell lymphoma: a study from the Lunenburg Lymphoma Biomarker Consortium. Blood. 2011; 117:7070-8.

19. Hong F, Kahl BS, Gray R. Incremental value in outcome prediction with gene expression-based signatures in diffuse large B-cell lymphoma. Blood. 2013; 121:156-8.

20. Oki Y, Noorani M, Lin P, Davis RE, Neelapu SS, Ma L, Ahmed M, Rodriguez MA, Hagemeister FB, Fowler N, Wang M, Fanale MA, Nastoupil L, et al. Double hit lymphoma: the MD Anderson Cancer Center clinical experience. Br J Haematol. 2014; 166:891-901.

21. Miller TP, Dahlberg S, Cassady JR, Adelstein DJ, Spier CM, Grogan TM, LeBlanc M, Carlin S, Chase E, Fisher RI. Chemotherapy Alone Compared with Chemotherapy plus Radiotherapy for Localized Intermediate- and High-Grade Non-Hodgkin's Lymphoma. N Engl J Med. 1998; 339:21-6.

22. Bonnet C, Fillet G, Mounier N, Ganem G, Molina TJ, Thiéblemont C, Fermé C, Quesnel B, Martin C, Gisselbrecht C, Tilly H, Reyes F; Groupe d'Etude des Lymphomes de l'Adulte. CHOP Alone Compared With CHOP Plus Radiotherapy for Localized Aggressive Lymphoma in Elderly Patients: A Study by the Groupe d'Etude des Lymphomes de l'Adulte. J Clin Oncol. 2007; 25:787-92.

23. Lamy T, Damaj G, Soubeyran P, Gyan E, Cartron G, Bouabdallah K, Gressin R, Cornillon J, Banos A, Le Du $\mathrm{K}$, Benchalal M, Moles MP, Le Gouill S, et al. R-CHOP 14 with or without radiotherapy in nonbulky limited-stage diffuse large B-cell lymphoma. Blood. 2018; 131:174-81.

24. German High-Grade Non-Hodgkin's Lymphoma Study Group. Rituximab and Combination Chemotherapy With or Without Radiation Therapy in Treating Patients With B-Cell Non-Hodgkin's Lymphoma. January 18. 2006. Available 2017 Nov 16, from https://clinicaltrials.gov/ct2/ show/NCT00278408.

25. Coiffier B, Lepage E, Brière J, Herbrecht R, Tilly H, Bouabdallah R, Morel P, Van Den Neste E, Salles G, Gaulard P, Reyes F, Lederlin P, Gisselbrecht C. CHOP
Chemotherapy plus Rituximab Compared with CHOP Alone in Elderly Patients with Diffuse Large-B-Cell Lymphoma. N Engl J Med. 2002; 346:235-42.

26. Feugier P, Van Hoof A, Sebban C, Solal-Celigny P, Bouabdallah R, Fermé C, Christian B, Lepage E, Tilly H, Morschhauser F, Gaulard P, Salles G, Bosly A, et al. LongTerm Results of the R-CHOP Study in the Treatment of Elderly Patients With Diffuse Large B-Cell Lymphoma: A Study by the Groupe d'Etude des Lymphomes de l'Adulte. J Clin Oncol. 2005; 23:4117-26.

27. Pfreundschuh M, Schubert J, Ziepert M, Schmits R, Mohren M, Lengfelder E, Reiser M, Nickenig C, Clemens M, Peter N, Bokemeyer C, Eimermacher H, Ho A, et al. Six versus eight cycles of bi-weekly CHOP-14 with or without rituximab in elderly patients with aggressive CD20+ B-cell lymphomas: a randomised controlled trial (RICOVER-60). Lancet Oncol. 2008; 9:105-16.

28. Cunningham D, Hawkes EA, Jack A, Qian W, Smith P, Mouncey P, Pocock C, Ardeshna KM, Radford JA, McMillan A, Davies J, Turner D, Kruger A, et al. Rituximab plus cyclophosphamide, doxorubicin, vincristine, and prednisolone in patients with newly diagnosed diffuse large B-cell non-Hodgkin lymphoma: a phase 3 comparison of dose intensification with 14-day versus 21-day cycles. Lancet. 2013; 381:1817-26.

29. Delarue R, Tilly H, Mounier N, Petrella T, Salles G, Thieblemont $\mathrm{C}$, Bologna $\mathrm{S}$, Ghesquières $\mathrm{H}$, Hacini $\mathrm{M}$, Fruchart C, Ysebaert L, Fermé C, Casasnovas O, et al. Dose-dense rituximab-CHOP compared with standard rituximab-CHOP in elderly patients with diffuse large B-cell lymphoma (the LNH03-6B study): a randomised phase 3 trial. Lancet Oncol. 2013; 14:525-33.

30. Offner F, Samoilova O, Osmanov E, Eom HS, Topp MS, Raposo J, Pavlov V, Ricci D, Chaturvedi S, Zhu E, van de Velde H, Enny C, Rizo A, et al. Frontline rituximab, cyclophosphamide, doxorubicin, and prednisone with bortezomib (VR-CAP) or vincristine (R-CHOP) for nonGCB DLBCL. Blood. 2015; 126:1893-901.

31. Vitolo U, Trněný M, Belada D, Burke JM, Carella AM, Chua N, Abrisqueta P, Demeter J, Flinn I, Hong X, Kim WS, Pinto A, Shi YK, et al. Obinutuzumab or Rituximab Plus Cyclophosphamide, Doxorubicin, Vincristine, and Prednisone in Previously Untreated Diffuse Large B-Cell Lymphoma. J Clin Oncol. 2017; 35:3529-37.

32. Held G, Murawski N, Ziepert M, Fleckenstein J, Pöschel V, Zwick C, Bittenbring J, Hänel M, Wilhelm S, Schubert J, Schmitz N, Löffler M, Rübe C, et al. Role of Radiotherapy to Bulky Disease in Elderly Patients With Aggressive B-Cell Lymphoma. J Clin Oncol. 2014; 32:1112-8.

33. Pfreundschuh M, Trümper L, Österborg A, Pettengell R, Trneny M, Imrie K, Ma D, Gill D, Walewski J, Zinzani PL, Stahel R, Kvaloy S, Shpilberg O, et al. CHOPlike chemotherapy plus rituximab versus CHOP-like chemotherapy alone in young patients with good-prognosis diffuse large-B-cell lymphoma: a randomised controlled 
trial by the MabThera International Trial (MInT) Group. Lancet Oncol. 2006; 7:379-91.

34. Pfreundschuh M, Kuhnt E, Trümper L, Osterborg A, Trneny M, Shepherd L, Gill DS, Walewski J, Pettengell R, Jaeger U, Zinzani PL, Shpilberg O, Kvaloy S, et al. CHOP-like chemotherapy with or without rituximab in young patients with good-prognosis diffuse large-B-cell lymphoma: 6-year results of an open-label randomised study of the MabThera International Trial (MInT) Group. Lancet Oncol. 2011; 12:1013-22.

35. Récher C, Coiffier B, Haioun C, Molina TJ, Fermé C, Casasnovas O, Thiéblemont C, Bosly A, Laurent G, Morschhauser F, Ghesquières H, Jardin F, Bologna S, et al. Intensified chemotherapy with ACVBP plus rituximab versus standard $\mathrm{CHOP}$ plus rituximab for the treatment of diffuse large B-cell lymphoma (LNH03-2B): an open-label randomised phase 3 trial. Lancet. 2011; 378:1858-67.

36. Molina TJ, Canioni D, Copie-Bergman C, Recher C, Brière J, Haioun C, Berger F, Fermé C, Copin MC, Casasnovas O, Thieblemont C, Petrella T, Leroy K, et al. Young patients with non-germinal center B-cell-like diffuse large B-cell lymphoma benefit from intensified chemotherapy with ACVBP plus rituximab compared with CHOP plus rituximab: analysis of data from the Groupe d'Etudes des Lymphomes de l'Adulte/lymphoma study association phase III trial LNH 03-2B. J Clin Oncol. 2014; 32:3996-4003.

37. Purroy N, Bergua J, Gallur L, Prieto J, Lopez LA, Sancho JM, García-Marco JA, Castellví J, Montes-Moreno S, Batlle A, de Villambrosia SG, Carnicero F, Ferrando-Lamana L, et al. Long-term follow-up of dose-adjusted EPOCH plus rituximab (DA-EPOCH-R) in untreated patients with poor prognosis large B-cell lymphoma. A phase II study conducted by the Spanish PETHEMA Group. Br J Haematol. 2015; 169:188-98.

38. Wilson WH, Sin-Ho J, Pitcher BN, Hsi ED, Friedberg J, Cheson B, Bartlett NL, Smith S, Johnston NW, Kahl BS, Staudt LM, Blum K, Abramson J, et al. Phase III Randomized Study of R-CHOP Versus DA-EPOCH-R and Molecular Analysis of Untreated Diffuse Large B-Cell Lymphoma: CALGB/Alliance 50303. Blood. 2016; 128: 469LP-469.

39. Stiff PJ, Unger JM, Cook JR, Constine LS, Couban S, Stewart DA, Shea TC, Porcu P, Winter JN, Kahl BS, Miller TP, Tubbs RR, Marcellus D, et al. Autologous Transplantation as Consolidation for Aggressive NonHodgkin's Lymphoma. N Engl J Med. 2013; 369:1681-90.

40. Peyrade F, Jardin F, Thieblemont C, Thyss A, Emile JF, Castaigne S, Coiffier B, Haioun C, Bologna S, Fitoussi O, Lepeu G, Fruchart C, Bordessoule D, et al. Attenuated immunochemotherapy regimen (R-miniCHOP) in elderly patients older than 80 years with diffuse large B-cell lymphoma: a multicentre, single-arm, phase 2 trial. Lancet Oncol. 2011; 12:460-8.

41. Fields PA, Townsend W, Webb A, Counsell N, Pocock C, Smith P, Jack A, El-Mehidi N, Johnson PW, Radford
J, Linch DC, Cunnningham D. De Novo Treatment of Diffuse Large B-Cell Lymphoma With Rituximab, Cyclophosphamide, Vincristine, Gemcitabine, and Prednisolone in Patients With Cardiac Comorbidity: A United Kingdom National Cancer Research Institute Trial. J Clin Oncol. 2014; 32:282-7.

42. Luminari S, Montanini A, Caballero D, Bologna S, Notter M, Dyer MJ, Chiappella A, Briones J, Petrini M, Barbato A, Kayitalire L, Federico M. Nonpegylated liposomal doxorubicin (MyocetTM) combination (R-COMP) chemotherapy in elderly patients with diffuse large B-cell lymphoma (DLBCL): results from the phase II EUR018 trial. Ann Oncol. 2010; 21:1492-9.

43. Oki Y, Ewer MS, Lenihan DJ, Fisch MJ, Hagemeister FB, Fanale M, Romaguera J, Pro B, Fowler N, Younes A, Astrow AB, Huang X, Kwak LW, et al. Pegylated Liposomal Doxorubicin Replacing Conventional Doxorubicin in Standard R-CHOP Chemotherapy for Elderly Patients With Diffuse Large B-Cell Lymphoma: An Open Label, Single Arm, Phase II Trial. Clin Lymphoma Myeloma Leuk. 2015; 15:152-8.

44. Philip T, Guglielmi C, Hagenbeek A, Somers R, Van Der Lelie H, Bron D, Sonneveld P, Gisselbrecht C, Cahn JY, Harousseau JL, Coiffier B, Biron P, Mandelli F, et al. Autologous Bone Marrow Transplantation as Compared with Salvage Chemotherapy in Relapses of ChemotherapySensitive Non-Hodgkin's Lymphoma. N Engl J Med. 1995; 333:1540-5.

45. Gisselbrecht C, Glass B, Mounier N, Singh Gill D, Linch DC, Trneny M, Bosly A, Ketterer N, Shpilberg O, Hagberg $\mathrm{H}$, Ma D, Brière J, Moskowitz CH, et al. Salvage Regimens With Autologous Transplantation for Relapsed Large B-Cell Lymphoma in the Rituximab Era. J Clin Oncol. 2010; 28:4184-90.

46. Crump M, Kuruvilla J, Couban S, MacDonald DA, Kukreti V, Kouroukis CT, Rubinger M, Buckstein R, Imrie KR, Federico M, Di Renzo N, Howson-Jan K, Baetz T, et al. Randomized Comparison of Gemcitabine, Dexamethasone, and Cisplatin Versus Dexamethasone, Cytarabine, and Cisplatin Chemotherapy Before Autologous Stem-Cell Transplantation for Relapsed and Refractory Aggressive Lymphomas: NCIC-CTG LY.12. J Clin Oncol. 2014; 32:3490-6.

47. Martín A, Conde E, Arnan M, Canales MA, Deben G, Sancho JM, Andreu R, Salar A, García-Sanchez P, Vázquez L, Nistal S, Requena MJ, Donato EM, et al. R-ESHAP as salvage therapy for patients with relapsed or refractory diffuse large B-cell lymphoma: the influence of prior exposure to rituximab on outcome. A GELTAMO study. Haematologica. 2008; 93:1829-36.

48. van Imhoff GW, McMillan A, Matasar MJ, Radford J, Ardeshna KM, Kuliczkowski K, Kim W, Hong X, Goerloev JS, Davies A, Barrigón MDC, Ogura M, Leppä S, et al. Ofatumumab Versus Rituximab Salvage Chemoimmunotherapy in Relapsed or Refractory Diffuse 
Large B-Cell Lymphoma: The ORCHARRD Study. J Clin Oncol. 2017; 35:544-51.

49. Derenzini E, Musuraca G, Fanti S, Stefoni V, Tani M, Alinari L, Venturini F, Gandolfi L, Baccarani M, Zinzani PL. Pretransplantation positron emission tomography scan is the main predictor of autologous stem cell transplantation outcome in aggressive B-cell non-Hodgkin lymphoma. Cancer. 2008; 113:2496-503.

50. Sauter CS, Matasar MJ, Meikle J, Schoder H, Ulaner GA, Migliacci JC, Hilden P, Devlin SM, Zelenetz AD, Moskowitz CH. Prognostic value of FDG-PET prior to autologous stem cell transplantation for relapsed and refractory diffuse large B-cell lymphoma. Blood. 2015; 125:2579-81.

51. Vose JM, Carter S, Burns LJ, Ayala E, Press OW, Moskowitz CH, Stadtmauer EA, Mineshi S, Ambinder R, Fenske T, Horowitz M, Fisher R, Tomblyn M. Phase III Randomized Study of Rituximab/Carmustine, Etoposide, Cytarabine, and Melphalan (BEAM) Compared With Iodine-131 Tositumomab/BEAM With Autologous Hematopoietic Cell Transplantation for Relapsed Diffuse Large B-Cell Lymphoma: Results From the BMT CTN 0401 Trial. J Clin Oncol. 2013; 31:1662-8.

52. Gisselbrecht C, Schmitz N, Mounier N, Singh Gill D, Linch DC, Trneny M, Bosly A, Milpied NJ, Radford J, Ketterer N, Shpilberg O, Dührsen U, Hagberg H, et al. Rituximab maintenance therapy after autologous stem-cell transplantation in patients with relapsed CD20(+) diffuse large B-cell lymphoma: final analysis of the collaborative trial in relapsed aggressive lymphoma. J Clin Oncol. 2012; 30:4462-9.

53. Escalón MP, Champlin RE, Saliba RM, Acholonu SA, Hosing C, Fayad L, Giralt S, Ueno NT, Maadani F, Pro B, Donato M, McLaughlin P, Khouri IF. Nonmyeloablative allogeneic hematopoietic transplantation: a promising salvage therapy for patients with non-Hodgkin's lymphoma whose disease has failed a prior autologous transplantation. J Clin Oncol. 2004; 22:2419-23.

54. Thomson KJ, Morris EC, Bloor A, Cook G, Milligan D, Parker A, Clark F, Yung L, Linch DC, Chakraverty R, Peggs KS, Mackinnon S. Favorable Long-Term Survival After Reduced-Intensity Allogeneic Transplantation for Multiple-Relapse Aggressive Non-Hodgkin's Lymphoma. J Clin Oncol. 2009; 27:426-32.

55. van Kampen RJ, Canals C, Schouten HC, Nagler A, Thomson KJ, Vernant JP, Buzyn A, Boogaerts MA, Luan JJ, Maury S, Milpied NJ, Jouet JP, Ossenkoppele GJ, et al. Allogeneic Stem-Cell Transplantation As Salvage Therapy for Patients With Diffuse Large B-Cell Non-Hodgkin's Lymphoma Relapsing After an Autologous Stem-Cell Transplantation: An Analysis of the European Group for Blood and Marrow Transplantation Registry. J Clin Oncol. 2011; 29:1342-8.

56. Ulaner GA, Goldman DA, Sauter CS, Migliacci J, Lilienstein J, Gönen M, Schöder H, Moskowitz CH,
Zelenetz AD. Prognostic Value of FDG PET/CT before Allogeneic and Autologous Stem Cell Transplantation for Aggressive Lymphoma. Radiology. 2015; 277:518-26.

57. Crump M, Neelapu SS, Farooq U, Van Den Neste E, Kuruvilla J, Westin J, Link BK, Hay A, Cerhan JR, Zhu L, Boussetta S, Feng L, Maurer MJ, et al. Outcomes in refractory diffuse large B-cell lymphoma: results from the international SCHOLAR-1 study. Blood. 2017; 130:1800-8.

58. Thieblemont C, Briere J, Mounier N, Voelker HU, Cuccuini W, Hirchaud E, Rosenwald A, Jack A, Sundstrom C, Cogliatti S, Trougouboff P, Boudova L, Ysebaert L, et al. The germinal center/activated B-cell subclassification has a prognostic impact for response to salvage therapy in relapsed/refractory diffuse large B-cell lymphoma: a bioCORAL study. J Clin Oncol. 2011; 29:4079-87.

59. López A, Gutiérrez A, Palacios A, Blancas I, Navarrete M, Morey M, Perelló A, Alarcón J, Martínez J, Rodríguez J. GEMOX-R regimen is a highly effective salvage regimen in patients with refractory/relapsing diffuse large-cell lymphoma: a phase II study. Eur J Haematol. 2007; 80:127-32.

60. Mounier N, El Gnaoui T, Tilly H, Canioni D, Sebban C, Casasnovas RO, Delarue R, Sonet A, Beaussart P, Petrella T, Castaigne S, Bologna S, Salles G, et al. Rituximab plus gemcitabine and oxaliplatin in patients with refractory/ relapsed diffuse large B-cell lymphoma who are not candidates for high-dose therapy. A phase II Lymphoma Study Association trial. Haematologica. 2013; 98:1726-31.

61. Vacirca JL, Acs PI, Tabbara IA, Rosen PJ, Lee P, Lynam E. Bendamustine combined with rituximab for patients with relapsed or refractory diffuse large B cell lymphoma. Ann Hematol. 2014; 93:403-9.

62. Pettengell R, Coiffier B, Narayanan G, de Mendoza FH, Digumarti R, Gomez H, Zinzani PL, Schiller G, Rizzieri D, Boland G, Cernohous P, Wang L, Kuepfer C, et al. Pixantrone dimaleate versus other chemotherapeutic agents as a single-agent salvage treatment in patients with relapsed or refractory aggressive non-Hodgkin lymphoma: a phase 3, multicentre, open-label, randomised trial. Lancet Oncol. 2012; 13:696-706.

63. Witzig TE, Vose JM, Zinzani PL, Reeder CB, Buckstein R, Polikoff JA, Bouabdallah R, Haioun C, Tilly H, Guo P, Pietronigro D, Ervin-Haynes AL, Czuczman MS. An international phase II trial of single-agent lenalidomide for relapsed or refractory aggressive B-cell non-Hodgkin's lymphoma. Ann Oncol. 2011; 22:1622-7.

64. Vose JM, Habermann TM, Czuczman MS, Zinzani PL, Reeder CB, Tuscano JM, Lossos IS, Li J, Pietronigro D, Witzig TE. Single-agent lenalidomide is active in patients with relapsed or refractory aggressive non-Hodgkin lymphoma who received prior stem cell transplantation. $\mathrm{Br}$ J Haematol. 2013; 162:639-47.

65. Fang C, Zhu D, Dong H, Ji M, Wu J, Xu X, Cheng G, Wu C, Jiang J. Lenalidomide alone or in combination with chemotherapy treatment for subtypes of diffuse large B cell 
lymphoma: a systematic review and meta-analysis. Int $\mathrm{J}$ Clin Exp Med. 2015; 8:10705-13.

66. El Bary NA, Hashem T, Metwally H, Ghany AA, El Mageed HA. A phase II study of high-dose celecoxib and metronomic 'low-dose' cyclophosphamide and methotrexate in patients with relapsed and refractory lymphoma. Hematol Oncol Stem Cell Ther. 2010; 3:13-8.

67. Coleman M, Martin P, Ruan J, Furman R, Niesvizky R, Elstrom R, George P, Kaufman TP, Leonard JP. Prednisone, etoposide, procarbazine, and cyclophosphamide (PEP-C) oral combination chemotherapy regimen for recurring/ refractory lymphoma: low-dose metronomic, multidrug therapy. Cancer. 2008; 112:2228-32.

68. Barrington SF, Mikhaeel NG, Kostakoglu L, Meignan M, Hutchings M, Müeller SP, Schwartz LH, Zucca E, Fisher RI, Trotman J, Hoekstra OS, Hicks RJ, O’Doherty MJ, et al. Role of Imaging in the Staging and Response Assessment of Lymphoma: Consensus of the International Conference on Malignant Lymphomas Imaging Working Group. J Clin Oncol. 2014; 32:3048-58.

69. Kasamon YL, Wahl RL, Ziessman HA, Blackford AL, Goodman SN, Fidyk CA, Rogers KM, Bolaños-Meade J, Borowitz MJ, Ambinder RF, Jones RJ, Swinnen LJ. Phase II study of risk-adapted therapy of newly diagnosed, aggressive non-Hodgkin lymphoma based on midtreatment FDG-PET scanning. Biol Blood Marrow Transplant. 2009; 15:242-8.

70. Pardal E, Coronado M, Martín A, Grande C, Marín-Niebla A, Panizo C, Bello JL, Conde E, Hernández MT, Arranz R, Bargay J, González-Barca E, Pérez-Ceballos E, et al. Intensification treatment based on early FDG-PET in patients with high-risk diffuse large B-cell lymphoma: a phase II GELTAMO trial. Br J Haematol. 2014; 167:327-36.

71. Thompson CA, Ghesquieres H, Maurer MJ, Cerhan JR, Biron P, Ansell SM, Chassagne-Clément C, Inwards DJ, Gargi T, Johnston PB, Nicolas-Virelizier E, Macon WR, Peix M, et al. Utility of Routine Post-Therapy Surveillance Imaging in Diffuse Large B-Cell Lymphoma. J Clin Oncol. 2014; 32:3506-12.

72. Peñalver FJ, Sancho JM, de la Fuente A, Olave MT, Martín A, Panizo C, Pérez E, Salar A, Orfao A; Spanish Lymphoma Group (GELTAMO). Guidelines for diagnosis, prevention and management of central nervous system involvement in diffuse large B-cell lymphoma patients by the Spanish Lymphoma Group (GELTAMO). Haematologica. 2017; 102:235-45.

73. Jones GL, Will A, Jackson GH, Webb NJ, Rule S; British Committee for Standards in Haematology. Guidelines for the management of tumour lysis syndrome in adults and children with haematological malignancies on behalf of the British Committee for Standards in Haematology. Br J Haematol. 2015; 169:661-71.

74. Cairo MS, Bishop M. Tumour lysis syndrome: new therapeutic strategies and classification. Br J Haematol. 2004; 127:3-11.
75. Cortes J, Moore JO, Maziarz RT, Wetzler M, Craig M, Matous J, Luger S, Dey BR, Schiller GJ, Pham D, Abboud CN, Krishnamurthy M, Brown A, et al. Control of plasma uric acid in adults at risk for tumor Lysis syndrome: efficacy and safety of rasburicase alone and rasburicase followed by allopurinol compared with allopurinol alone-results of a multicenter phase III study. J Clin Oncol. 2010; 28:4207-13.

76. Trifilio S, Gordon L, Singhal S, Tallman M, Evens A, Rashid K, Fishman M, Masino K, Pi J, Mehta J. Reduceddose rasburicase (recombinant xanthine oxidase) in adult cancer patients with hyperuricemia. Bone Marrow Transplant. 2006; 37:997-1001.

77. Castillo JJ, Bibas M, Miranda RN. The biology and treatment of plasmablastic lymphoma. Blood. 2015; 125:2323-30.

78. Castillo JJ, Winer ES, Stachurski D, Perez K, Jabbour M, Milani C, Colvin GA, Butera JN. HIV-Negative Plasmablastic Lymphoma: Not in the Mouth. Clin Lymphoma Myeloma Leuk. 2011; 11:185-9.

79. Castillo JJ, Furman M, Beltrán BE, Bibas M, Bower M, Chen W, Díez-Martín JL, Liu JJ, Miranda RN, Montoto S, Nanaji NM, Navarro JT, Seegmiller AC, et al. Human immunodeficiency virus-associated plasmablastic lymphoma: poor prognosis in the era of highly active antiretroviral therapy. Cancer. 2012; 118:5270-7.

80. Castillo JJ, Winer ES, Stachurski D, Perez K, Jabbour M, Milani C, Colvin G, Butera JN. Prognostic factors in chemotherapy-treated patients with HIV-associated Plasmablastic lymphoma. Oncologist. 2010; 15:293-9.

81. Al-Malki MM, Castillo JJ, Sloan JM, Re A. Hematopoietic cell transplantation for plasmablastic lymphoma: a review. Biol Blood Marrow Transplant. 2014; 20:1877-84.

82. Cattaneo C, Re A, Ungari M, Peli A, Casari S, Castelnuovo F, Fisogni S, Lonardi S, Pellegrini V, Petullà M, Facchetti F, Rossi G. Plasmablastic lymphoma among human immunodeficiency virus-positive patients: results of a single center's experience. Leuk Lymphoma. 2015; 56:267-9.

83. Liu JJ, Zhang L, Ayala E, Field T, Ochoa-Bayona JL, Perez L, Bello CM, Chervenick PA, Bruno S, Cultrera JL, Baz RC, Kharfan-Dabaja MA, Raychaudhuri J, et al. Human immunodeficiency virus (HIV)-negative plasmablastic lymphoma: a single institutional experience and literature review. Leuk Res. 2011; 35:1571-7.

84. Castillo JJ, Reagan JL, Sikov WM, Winer ES. Bortezomib in combination with infusional dose-adjusted EPOCH for the treatment of plasmablastic lymphoma. Br J Haematol. 2015; 169:352-5.

85. Fernandez-Alvarez R, Gonzalez-Rodriguez AP, RubioCastro A, Gonzalez ME, Payer AR, Alonso-Garcia A, Rodriguez-Villar D, Dominguez-Iglesias F, Sancho JM. Bortezomib plus CHOP for the treatment of HIV-associated plasmablastic lymphoma: clinical experience in three patients. Leuk Lymphoma. 2015; 57:1-4. 
86. Dunleavy K, Pittaluga S, Maeda LS, Advani R, Chen CC, Hessler J, Steinberg SM, Grant C, Wright G, Varma G, Staudt LM, Jaffe ES, Wilson WH. Dose-adjusted EPOCHrituximab therapy in primary mediastinal B-cell lymphoma. N Engl J Med. 2013; 368:1408-16.

87. Bhatt VR, Mourya R, Shrestha R, Armitage JO. Primary mediastinal large B-cell lymphoma. Cancer Treat Rev. 2015; 41:476-85.

88. Rieger M, Osterborg A, Pettengell R, White D, Gill D, Walewski J, Kuhnt E, Loeffler M, Pfreundschuh M, Ho AD; MabThera International Trial (MInT) Group. Primary mediastinal B-cell lymphoma treated with CHOPlike chemotherapy with or without rituximab: results of the Mabthera International Trial Group study. Ann Oncol. 2011; 22:664-70.

89. Xu LM, Fang H, Wang WH, Jin J, Wang SL, Liu YP, Song YW, Ren H, Zhou LQ, Li YX. Prognostic significance of rituximab and radiotherapy for patients with primary mediastinal large B-cell lymphoma receiving doxorubicincontaining chemotherapy. Leuk Lymphoma. 2013; 54:1684-90.

90. Giri S, Bhatt VR, Pathak R, Bociek RG, Vose JM, Armitage $\mathrm{JO}$. Role of radiation therapy in primary mediastinal large B-cell lymphoma in rituximab era: A US population-based analysis. Am J Hematol. 2015; 90:1052-4.

91. Zinzani PL, Martelli M, Bertini M, Gianni AM, Devizzi L, Federico M, Pangalis G, Michels J, Zucca E, Cantonetti M, Cortelazzo S, Wotherspoon A, Ferreri AJM, et al. Induction chemotherapy strategies for primary mediastinal large B-cell lymphoma with sclerosis: a retrospective multinational study on 426 previously untreated patients. Haematologica. 2002; 87:1258-64.

92. Dabrowska-Iwanicka A, Walewski JA. Primary mediastinal large B-cell lymphoma. Curr Hematol Malig Rep. 2014; 9:273-83.

93. Kuruvilla J, Pintilie M, Tsang R, Nagy T, Keating A, Crump M. Salvage chemotherapy and autologous stem cell transplantation are inferior for relapsed or refractory primary mediastinal large B-cell lymphoma compared with diffuse large B-cell lymphoma. Leuk Lymphoma. 2008; 49:1329-36.

94. Sarkozy C, Traverse-Glehen A, Coiffier B. Double-hit and double-protein-expression lymphomas: aggressive and refractory lymphomas. Lancet Oncol. 2015; 16:e555-67.

95. Le Gouill S, Talmant P, Touzeau C, Moreau A, Garand R, Juge-Morineau N, Gaillard F, Gastinne T, Milpied N, Moreau P, Harousseau JL, Avet-Loiseau H. The clinical presentation and prognosis of diffuse large B-cell lymphoma with $\mathrm{t}(14 ; 18)$ and $8 \mathrm{q} 24 / \mathrm{c}-\mathrm{MYC}$ rearrangement. Haematologica. 2007; 92:1335-42.

96. Niitsu N, Okamoto M, Miura I, Hirano M. Clinical features and prognosis of de novo diffuse large B-cell lymphoma with $\mathrm{t}(14 ; 18)$ and $8 \mathrm{q} 24 / \mathrm{c}-\mathrm{MYC}$ translocations. Leukemia. 2009; 23:777-83.
97. Dunleavy K, Fanale M, LaCasce A, Noy A, Caimi P, Parekh S, Hayslip JW, Jagadeesh D, Lord RS, Lechowicz MJ, Gaur R, Lucas A, Staudt LM, et al. Preliminary Report of a Multicenter Prospective Phase II Study of DA-EPOCH-R in MYC-Rearranged Aggressive B-Cell Lymphoma. Blood. 2014; $124: 395$.

98. Howlett C, Snedecor SJ, Landsburg DJ, Svoboda J, Chong EA, Schuster SJ, Nasta SD, Feldman T, Rago A, Walsh KM, Weber S, Goy A, Mato A. Front-line, dose-escalated immunochemotherapy is associated with a significant progression-free survival advantage in patients with doublehit lymphomas: a systematic review and meta-analysis. Br J Haematol. 2015; 170:504-14.

99. Herrera AF, Mei M, Low L, Kim HT, Griffin GK, Song JY, Merryman RW, Bedell V, Pak C, Sun H, Paris T, Stiller T, Brown JR, et al. Relapsed or Refractory Double-Expressor and Double-Hit Lymphomas Have Inferior ProgressionFree Survival After Autologous Stem-Cell Transplantation. J Clin Oncol. 2017; 35:24-31.

100. Petrich AM, Gandhi M, Jovanovic B, Castillo JJ, Rajguru S, Yang DT, Shah KA, Whyman JD, Lansigan F, HernandezIlizaliturri FJ, Lee LX, Barta SK, Melinamani S, et al. Impact of induction regimen and stem cell transplantation on outcomes in double-hit lymphoma: a multicenter retrospective analysis. Blood. 2014; 124:2354-61.

101. Navarro JT, Lloveras N, Ribera JM, Oriol A, Mate JL, Feliu E. The prognosis of HIV-infected patients with diffuse large B-cell lymphoma treated with chemotherapy and highly active antiretroviral therapy is similar to that of HIVnegative patients receiving chemotherapy. Haematologica. 2005; 90:704-6.

102. Díez-Martín JL, Balsalobre P, Re A, Michieli M, Ribera JM, Canals C, Conde E, Rosselet A, Gabriel I, Varela R, Allione B, Cwynarski K, Genet P, et al. Comparable survival between HIV+ and HIV- non-Hodgkin and Hodgkin lymphoma patients undergoing autologous peripheral blood stem cell transplantation. Blood. 2009; 113:6011-4.

103. Sarker D, Thirlwell C, Nelson M, Gazzard B, Bower M. Leptomeningeal disease in AIDS-related non-Hodgkin's lymphoma. AIDS. 2003; 17:861-5.

104. Reshef R, Vardhanabhuti S, Luskin MR, Heitjan DF, Hadjiliadis D, Goral S, Krok KL, Goldberg LR, Porter DL, Stadtmauer EA, Tsai DE. Reduction of immunosuppression as initial therapy for posttransplantation lymphoproliferative disorder( $\star$ ). Am J Transplant. 2011; 11:336-47.

105. González-Barca E, Domingo-Domenech E, Capote FJ, Gómez-Codina J, Salar A, Bailen A, Ribera JM, López A, Briones J, Muñoz A, Encuentra M, de Sevilla AF; GEL/ TAMO (Grupo Español de Linfomas), et al. Prospective phase II trial of extended treatment with rituximab in patients with B-cell post-transplant lymphoproliferative disease. Haematologica. 2007; 92:1489-94.

106. Trappe R, Oertel S, Leblond V, Mollee P, Sender M, Reinke P, Neuhaus R, Lehmkuhl H, Horst HA, Salles G, Morschhauser F, Jaccard A, Lamy T, et al. Sequential 
treatment with rituximab followed by CHOP chemotherapy in adult B-cell post-transplant lymphoproliferative disorder (PTLD): the prospective international multicentre phase 2 PTLD-1 trial. Lancet Oncol. 2012; 13:196-206.

107. Haque T, Wilkie GM, Jones MM, Higgins CD, Urquhart G, Wingate $P$, Burns D, McAulay $K$, Turner M, Bellamy C, Amlot PL, Kelly D, MacGilchrist A, et al. Allogeneic cytotoxic T-cell therapy for EBV-positive posttransplantation lymphoproliferative disease: results of a phase 2 multicenter clinical trial. Blood. 2007; 110:1123-31.
108. Icheva V, Kayser S, Wolff D, Tuve S, Kyzirakos C, Bethge W, Greil J, Albert MH, Schwinger W, Nathrath M, Schumm M, Stevanovic S, Handgretinger R, et al. Adoptive transfer of epstein-barr virus (EBV) nuclear antigen 1-specific t cells as treatment for EBV reactivation and lymphoproliferative disorders after allogeneic stem-cell transplantation. J Clin Oncol. 2013; 31:39-48.

109. Choquet S, Varnous S, Deback C, Golmard JL, Leblond V. Adapted treatment of Epstein-Barr virus infection to prevent posttransplant lymphoproliferative disorder after heart transplantation. Am J Transplant. 2014; 14:857-66. 